\title{
On the Regional Rootedness of Population Mobility and Environmental Change
}

\author{
Felicitas Hillmann, Ernst Spaan
}

\begin{abstract}
This article argues that the interplay of changing environmental conditions in the wake of climate change and dynamic migration systems will lead to even more clearly articulated new regional formations. The way regions perceive the risks of climate change, how they cope with and adapt to these risks and their constitution as resilient entities determines the way migration and mobility take place. We focus on the regional dimensions of climate change and broader related developmental trends such as urbanisation and will highlight this nexus for coastal regions. We present two regional case studies, Keta in Ghana and Semarang in Indonesia. Both cities have experienced floods and related environmental risks throughout their histories. The contrasting analysis of the two cases illustrates that similar environmental challenges may have very different effects on the migratory patterns.
\end{abstract}

Keywords: Migration · Environmental Change $\cdot$ Region $\cdot$ Development $\cdot$ Diaspora

\section{Introduction}

In the past years, a notable increase in research on the relationship between climate change and population redistribution, i.e. migration, has occurred. The academic debate is multifaceted, it links to two mega trends: first, the exacerbation of environmental degradation through climate change; and second, population dynamics and migratory movements. The two debates cover somewhat different fields of knowledge: while the analysis of and the argumentation on environmental change is mainly tied to the natural sciences and mostly relies on quantitative data, the analysis of population dynamics and migration is deeply embedded in the social sciences and makes use of both quantitative and qualitative data. Currently, these two fields show similar difficulties when it comes to definitions concerning the dimensions of the phenomenon (How many people? How much environmental degradation?) and its temporalities (Permanent or temporary movements? Rapid or slow environmental change?). The key concepts are generally employed in an imprecise 
manner. Global observations are taken into account at times, sometimes quoting estimates of how much migration will be caused by various degrees of sea-level rise. There is also a large body of literature using case studies to illustrate specific local situations. Many regions experience environmental degradation, but show very different capacities to cope with the changes. Migration is among the most relevant adaptation strategies and is thus in the core of our analysis.

This article frames environmental change and processes of population mobility in a dynamic perspective by emphasizing the importance of the existing regional settings and trends. Rather than viewing climate change as a global phenomenon resulting in a variety of local consequences including population mobility, we argue for a perspective that interprets migration and environmental change as two separate processes that intersect under certain circumstances and at certain points in time. We favour a regional analysis that accentuates the man-made dimension of environmental change by linking ongoing socio-economic transformation processes such as rapid urbanisation to longstanding population dynamics. As this article shows, rapid-onset events such as frequent flooding may result in migration in some places, but not in others. Except for resettlement due to acute crises, migration propensity and patterns are firmly tied to the regional economic and sociocultural context.

This article focuses on the situation in coastal regions, which are generally among the most vulnerable to climate change. Coastlines are also known to be conducive to highly dynamic population movement and economic development, both due to linking the hinterland to the coast and as an access point for international socio-economic circuits. This article uses a comparative perspective. It contrasts two cities that experienced flooding for many years. The empirical data presented in this article is drawn from a larger research project carried out between 2014 and 2016 (see footnotes 1, 4 and 9 for more detail on methodology). ${ }^{1}$

In the first section, this article presents an overview of the state of the debate on climate change and migration by summarising its pitfalls. The second section offers a short regionalisation of environmental change connected to climate change. To empirically substantiate the theoretical argument, the third section focuses on two coastal areas that have experienced environmental change for a long time: (A) Keta, which is located on the Gulf of Guinea in Ghana and (B) Semarang, situated on the northern coastline of Java in Indonesia. Here, we first point out the main national features concerning the history of population dynamics, the speed and form

1 The project "New regional formations: Environmental change and migration in coastal areas in Ghana and Indonesia" (2014-2016) was generously funded by the Volkswagen-Stiftung (Germany). It was a joint project between the University of Bremen, Leibniz-Institute for Research on Society and Space Erkner, ZMT Bremen and KWI Essen. The empirical results presented here are the outcome of as well quantitative (use of existing demographic data and own survey and data) and qualitative research (including expert interviews, interviews with migrants, focusgroup discussions and observation, scrutinising of local reports and media) in the two regions as gathered by subproject 3 on "migrant trajectories". Also, the authors wish to thank Usha Ziegelmayer and two anonymous reviewers for their highly valuable comments on a former version of this manuscript. 
of urbanisation, the socio-economic setting and development policies. In a second step, the two regional examples are analysed by interpreting the collected data. The conclusions argue that a detailed regional analysis reveals results that contradict common assumptions of a neat causality between climate change and population mobility.

\section{State of the art: The role of climate change in population studies}

Early migration literature such as Ravenstein (1885) mentioned climate as one factor influencing migration behaviour. Petersen (1958) assumed that "primitive migration" was the result of an ecological push: a movement related to man's inability to cope with natural forces. From the 1960s onwards, this perspective received little attention, with rare exceptions such as Richmond (quoted in Hugo 1996: 110). Mainstream migration studies after World War II basically concentrated on economic circumstances, operating with the analytical tool of push and pull factors such as income differentials and employment opportunities while disregarding regional circumstances (Todaro 1976). Meanwhile, Neo-Marxist macro-theory emphasized political-economic factors and paid little attention to environmental influences. The bulk of migration literature considered the issues of migrant assimilation in urban areas at arrival, employing a predominantly culturalist approach (which ethnic groups adapts best?). Apparently, the economic boom in the industrialised world left little space for the investigation of the eventual impact of environmental change on migration in these years (1960-1980). Furthermore, the social sciences developed quantitative analysis systems that rarely considered the relevance of the geographical setting and its ecological dimensions. From the late 1970s onwards, with the beginning debate on sustainability, the production of knowledge in the field of environmental change and migration took a new turn. The report of the Club of Rome (1972), among the first voices to introduce ecological concerns into the development debate, identified five fields threatening economic growth: population increase, unbalanced food production, industrialisation, pollution, and the depletion of natural resources. A literature review identified a total of 39 publications covering the nexus of climate change and migration in the 1980s. In the 1990s, 104 publications could be found, and between 2000 and 2008179 publications were counted (Hillmann/Kronauer 2010). Today, the relationship between climate change and migration is at centre stage on the global political agenda.

The debate on a possible causality between climate change and migratory movements took off in the mid-1980s, when El-Hinnawi (1985) and other experts labelled certain migrants as "environmental refugees" in an UNEP report - pointing out that in the near future "the gravest effects of climate change may be those on human migration as millions will be displaced." (as cited in Piguet et al. 2011: 4). The debate intended to raise public awareness about environmental issues. When Myers (1983) published the first estimates and prognoses about the quantitative dimension of this category of migrants, the discussion took a new twist, as environmental degradation was now interpreted as a major cause of migration. In the ensuing years, the 
debate became increasingly alarmist. In 1995, a publication entitled "Environmental Exodus, An Emergent Crisis in the Global Arena" published by the Climate Institute (Washington, DC) obtained much attention (Myers/Kent 1995). The authors claimed that up to the year 2015, between 200 million to one billion people would be on the move due to environmental change. In 2006, the term "climate refugee" replaced the original "environmental refugee." The UN and several NGOs started to think about establishing a global humanitarian action plan, building upon the heated climate change debate of the day.

From the outset of the debate, this position - understanding environmental degradation as a direct cause of large-scale displacement - was referred to as the "maximalist position" (Suhrke 1994: 20). The opposing position was first taken by Richard Black in his book "Refugees, Environment and Development" (Black 1998). He claimed that the overall concept of environmental refugees was misleading and far too politicised, creating "horror scenarios," as Steven Castles (2002) put it. Etienne Piguet (2010) contends that, in addition to the weak empirical base of much of the work on environmental refugees, the suggested linear relationship is highly debatable. This latter position, mainly found among migration experts, was called the "minimalist position." In an early stage of the debate, Graeme Hugo pointed to environmental degradation (e.g. deforestation and pollution) in developing countries, but argued that many of the environmental changes were the results of all sorts of crises - including the refugee crisis itself. Additionally, the overexploitation of natural resources led to environmental degradation (Hugo 1996: 123).

Today, a wide range of studies on climate change exist, many of which have been funded by global organisations such as the IPCC, the World Bank, United Nations University, the OECD, as well as foundations such as the German Marshall Fund, the MacArthur Foundation, or NGOs such as the German Advisory Council on Global Change (WBGU) (2007). The EACH-FOR-project (Environmental Change and Forced Migration Scenarios), run in 2006 under the $6^{\text {th }}$ Framework Programme of the European Commission, was highly relevant for the empirical endorsement of the debate. The study was conceived in a multi-disciplinary manner, combining desk studies with case study research in almost two dozen locations. It incorporated parts of Europe into its design, but emphasized understanding the processes in developing countries. Up to 2010 , the focus of research was mostly on countries in the developing world, which were considered most vulnerable for climate change. From the outset, there was a regional emphasis on Africa (33 studies, with nine on Ghana) and Asia (36, with nine on Bangladesh) in empirical studies (Hillmann/Kronauer 2010). Most of the studies were designed as case studies, based on a short time frame and a limited number of study participants. Interdisciplinary and longitudinal research was lacking from the outset (KNOMAD 2015). This bias points towards Western fears concerning mass migration rather than indicating actual empirical trends (Piguet et al. 2011: 15), but also shows the political interests fuelling the debate from the side of the affected countries. Political representatives from states such as Bangladesh repeatedly expressed their concern about the effect of sea level rise on vulnerable coastal populations, contributing to the global awareness of a frightening development (Findlay/Geddes 2011: 138-139). Increasingly, migration 
was promoted as a top national concern in industrialised countries (Afifi/Warner 2008: 20). Some researchers also claim that there is a "climate divide" within most countries, whereby data and projections on climate change are available only for the economically thriving and politically influential parts of the country, even if other regions are more affected by climate change (Glaeser/Glaser 2010: 143). Existing institutional linkages between NGOs and established local partners in the developing world might be one factor that reinforced this regional selectivity.

In addition to this empirical bias, sudden environmental events such as cyclones, floods or volcanic eruptions have been at the centre of public debate because they require quick and reliable relocation and resettlement on the spot. Therefore, these events easily attract media and NGO attention. Longer-term effects of climate change that risk increased flooding (i.e. sea level rise and glacier melt) will potentially make coastlines uninhabitable in the future, but are difficult to foresee. Similarly, the increased frequency and magnitude of weather-related acute natural hazards are complex to grasp (KNOMAD 2015). Furthermore, root causes such as environmental degradation and resource loss due to large-scale infrastructure projects (Tsikata 2006; Bleibaum 2010), urbanisation, commercial farming practices, export-led development policies, and land tenures practices (Rogers/Wang 2006), all of which impact local livelihoods, are difficult to isolate. This means that they generally receive less attention compared to migration. However, Tacoli (2011: 1314) examines cycles of intensified environmental degradation and their devastating consequences on the livelihoods of people in Bolivia and Senegal occurring in conjunction with major economic and social upheaval. Recent phenomena, such as land-grabbing for producing biofuels instead of food crops, as well as the construction of infrastructure for mitigation itself (e.g. dams and water reservoirs or coastal sea defences), scarcely receive attention in the literature.

Migration then constitutes only one adaptation strategy among others, linking migratory events more strongly to local adaptation strategies, dependent upon the vulnerability and resilience of households. Intraregional migration is one such possible adaptation pattern, differing for women and men (McLeman/Hunter 2010; Laczko/Aghazarm 2009: 75). Anthropological literature explores whether the affected population can opt for other localised coping strategies, such as altered consumption patterns, changed cropping patterns, seasonal migration and income diversification. Some researchers also mention possible local solutions to coping with environmental change, such as adaption in situ (e.g. heightening floors of houses, economic diversification or short-distance mobility and shifts in crop production) (Handayani et al. 2015). Finally, questions of risk perception and the willingness to consider migration and other mobility as an option per se need to be taken into account by academic research (see van der Velde/Naerssen 2015 on the mental thresholds of migration).

Three analytical pitfalls can be identified for the current debate: a high degree of politicisation, the use of blurred terminologies, and the mixing and conflating of scales (e.g. local and global) (Hillmann et al. 2015). Interestingly, literature stemming from the affected countries themselves is likely to call for a multi-disciplinary approach for explaining migration realistically and for taking historical migration pat- 
terns into account (Awumbila/Ardayfio-Schandorf 2008; Laczko/Aghazarm 2009: 29; Muhidin 2014).

\section{Population Dynamics and Environmental change - a regionalisation}

In this article, "climate change" is used as the overarching term for global warming and, in consequence, sea level rise. In contrast, "Environmental change" is understood more broadly as including a vast array of degradations of the natural environment, very often man-made. Geographers in migration research (e.g. Richard Black) acknowledge the problems of sea level rise, desertification, deforestation, lack of water, salinisation and biodiversity depletion, but tend to interpret migration as an integrated part of the social and economic structure of the region in question. Similarly, Graeme Hugo stresses the impact of regional realities and acknowledges that morphology has an impact on the effects of climate change (Hugo 2013). He identifies four main terrains in which climate change is anticipated to have a negative impact when combined with population growth:

- Coastal areas: inundation, storm surges, and sea level rise

- River valleys and deltas: increased riparian flooding

- Low lying island states: sea level rise, surface warming, and extreme weather events

- Semi-arid and low humidity areas: water shortages

Of course, other morphological regions such as the high mountain regions, areas characterised by permafrost (e.g. parts of Russia), or the melting of the ice shields at the poles also undergo strong environmental change. In addition, the severity of the impact on the various types of areas is contingent on the type of human economic activities in the area.

Generally, the IPCC sees coastal areas in developing countries as highly vulnerable due to their comparatively low adaptive capacity - counting South, Southeast and East Asia and Africa as most vulnerable (IPCC 2014). In the case of Africa, it is expected that the low-lying coastal zones will experience high rates of population growth and urbanisation for decades to come, especially in Western and Eastern Africa (Neumann et al. 2015). In Asia, almost three-quarters of total population live in vulnerable low lying coastal zones (MacGranahan et al. 2007). The degradation of coastal and river delta ecosystems has detrimental impacts on the livelihoods of populations in these areas and is projected by the IPCC to lead to major population displacements, increasing pressure on scarce resources in destination areas. Poorer populations living in vulnerable coastal areas bear the brunt of environmental hazards. Their exposure leads to a higher risk in morbidity, property damage and livelihood loss, and subsequently could increase their propensity for migration. Therefore, this article concentrates on the analysis of coastal areas. 


\section{Regional examples of Population Dynamics and Environmental change in Ghana and Indonesia}

This article uses the two examples of Keta (Ghana) and Semarang (Indonesia) to investigate how local realities that have long been prone to rapid environmental change make use of migration as one possible adaptation strategy. Methodologically, the comparison aims to contrast two regional realities, not compare the two cases to one other. This approach allows for flexibility in the research design because it gives the researcher the possibility to reflect on one case in light of the other. The New Regional Formations project, which we refer to here (cf. Footnote 1), aimed at identifying the emergence of "new regional formations", new constellations of a variety of actors that reconnect local realities to greater development dynamics and that increasingly (re)position themselves on the regional level using the discourse on climate change as a vehicle for their policies (Herbeck 2015). Such new spatial and political configurations influence existing power symmetries within the nationstate, generate supranational governance structures, and are likely to become more powerful in the near future (Soja 2015: 373-374). The following section first summarises the common features of the two countries and then gives an introduction into the developmental, environmental and demographic characteristics of these national settings. Next, the two regional realities are presented separately. Here, the main findings of the survey and qualitative research will be presented.

\subsection{Common features of the two chosen examples}

The two regions chosen for empirical research are parts of larger national structures, which are themselves parts of supranational regional organisations (ECOWAS in Western Africa and ASEAN in Southeast Asia). Ghana and Indonesia are tightly linked to the global economy, and they show significant international migration flows. By HDI, both countries are classified as countries with "Medium Human Development", hosting a growing middle class population. Ghana and Indonesia have a predominantly young population, both countries face high poverty rates, inequality and situations of vulnerability among the major part of the population. The annual average population growth is around 2,5 percent in Ghana and 1,5 percent in Indonesia - each showing a slow but steady decrease of this rate since 1985. Life expectancy is about 60 years in Ghana and 70 years in Indonesia. Both countries are diverse in ethnicity and religion. Equally, the urban and rural populations are fairly balanced, showing an overall share of urbanisation of 53 percent for Indonesia and Ghana alike; the average rate of change of the share of urbanisation for 2010-15 is 1.3 percent (Ghana) and 1.5 percent (Indonesia) (United Nations 2014). Both Ghana and Indonesia were colonies until the 1950s, under British and Dutch administration, respectively.

The two countries are part of larger migratory systems - the West African and the Asia Pacific regimes - and have extensive diasporas. The net migration rates for the period $2010-15$ are $-0.8(-100,000$ migrants) and $-0.6(-700.000)$ for Ghana and Indonesia respectively (United Nations 2013b). In the 1960s and 1970s, Ghana was 
an important country of immigration, mainly attracting migrants from neighbouring countries to work on the plantations and in the timber industry. The mass expulsion in 1969 of a quarter of a million immigrants originating from Niger, Nigeria, Togo, and Burkina Faso marked the start of a decade of economic recession. Cocoa production slumped due to labour shortages, and, coupled with hyperinflation and droughts, caused severe economic recession. From then on, Ghana experienced a transition from an immigration to an emigration country, especially after oil was discovered in Nigeria. Many Ghanaians went to work in the oil industry, but the Ivory Coast and Togo were also countries of destination. In 1983 and 1985, there were mass forced expulsions from Nigeria, which included more than a million Ghanaians who were forced to return to Ghana, replacing many Burkinabé immigrants who (forcefully) returned home (Spaan/van Moppes 2006; Tankwanchi 2012). In recent decades, growing labour forces with bleak employment prospects, coupled with economic stagnation, have increasingly led to emigration. As in other West and East African countries in particular, the emigration of highly skilled workers, such as doctors, nurses, and architects, caused a brain-drain situation which has further exacerbated economic problems (Anyangwe/Mtonga 2007; Teye et al. 2014; Tankwanchi 2012).

In contrast, Indonesia shows a low net migration rate, although in absolute numbers international migration is significant, given Indonesia's population of almost 250 million. Traditionally, Indonesian labour migrants are low skilled workers, temporarily working abroad in agriculture, construction, and manufacturing, with the bulk of women working as domestic workers and caregivers. A large proportion of international labour migration is undocumented, particularly to neighbouring Malaysia and Singapore. The main destinations of Indonesian labour migrants are the Middle East (Saudi Arabia, Kuwait, the UAE, Qatar, and Jordan) and countries in Southeast and East Asia, such as Malaysia, Singapore, Hong Kong SAR, the Republic of Korea, and Taiwan. The Indonesian diaspora is estimated at 2-6 million and beyond the countries listed above can be found in Europe (Netherlands, United Kingdom, Germany, Italy, Sweden), Japan, Bangladesh, Papua New Guinea, Mauritius, Surinam, Australia and the Americas (Muhidin/Utomo 2013).

There are considerable regional differences in population growth and urbanisation rates in both countries. Greater Accra, Ashanti and Central regions in Ghana and the provinces of Banten, West-Java, Riau and East Kalimantan in Indonesia have the highest rates in their respective countries. Internal migration flows contribute to urban population growth in both countries. The general direction of migration in Ghana and Indonesia - from the north to coastal cities in the south in the case of Ghana, and from the outer islands to the coastal urban centres on Java in Indonesia - puts increasing pressure on the urban infrastructure and environment in the coastal regions of their countries.

Environmental change is a component of broad development problems. Deforestation is a major concern: between 1990 and 2011, forest area declined by 20.9 percent in Indonesia and 35.2 percent in Ghana (UNDP 2014). Although part of deforestation is caused by smallholder slash-and-burn agriculture and charcoal production, a major determining factor is a political economy favouring economic profit 
over conservation, backed by powerful interest groups including political elites and multinationals such as palm oil producers and mining companies (Hansen et al. 2009; Indrarto et al. 2012; Arnold 2014).

Both countries are faced by severe environmental issues in cities and coastal areas due to virtually non-existent recycling and waste processing. Further major environmental risks include sea level rise, floods, salinisation, mangrove forest depletion, pollution, and droughts. Both countries have implemented resettlement programs due to environmental problems, including those related to large infrastructural projects such as the erection of hydroelectric power plants and dams. Both coastlines either have a sea defence (Ghana) or will in the future (Indonesia) in 2017.

In Ghana, the development of an estate economy during colonial rule fostered historical patterns of in-migration from the country's north and from neighbouring countries. The main pattern of migration in Ghana has thus been from north to south, with a steadily increasing rate except for 1970-85, a period of economic decline. Most low-skilled migrants hailing from the north moved to the cities of Kumasi in Central Ghana and to coastal cities such as Accra, Cape Coast and Tema. Furthermore, many migrated to work in agriculture in the country's middle belt and cocoa farming in the southwest (Van der Geest 2011). From 2000-10, the highest population growth rates were recorded for Greater Accra and Central regions (3.1 percent), with lower rates for Northern Region (2.9 percent), Ashanti (2.7 percent) and Volta (2.5 percent). The poorest regions - Upper East (1.2 percent) and Upper West (1.9 percent) - recorded lowest rates (Ghana Statistical Service 2012).

Although it is often suggested that environmental degradation, exacerbated by changing climatic conditions (e.g. rising temperatures; erratic rainfall) is a main driver for out-migration, research in Ghana has shown that structural environmental scarcity and limited non-farm employment opportunities underlie population mobility patterns. Researchers have argued that poverty, the scarcity of arable land, and political factors ultimately weigh more heavily than environmental stress (Van der Geest 2011). Decentralisation and growth-pole strategies are drivers of mobility and urbanisation in Ghana (Yaro et al. 2011), and internal movement in Ghana is more prominent than in Indonesia (though smaller in absolute numbers). Ghana's fiveyear crude migration intensity (between 3.5-6 percent in 2000, measured in 10 and 110 regional units) is higher than that of Indonesia (between 0.8-4 percent in 2000, for 7 and 314 regions). Lifetime crude migration intensity in Ghana is 17.8-27.8 percent (2000, 10 and 110 regions), four times higher than in Indonesia (4.1-8.4 percent in 2000, for 7 and 26 regions) (United Nations 2013a: 8, 12). ${ }^{2}$

Indonesia is an island nation with over 240 million inhabitants (2010), half of whom live on the island of Java. Up to 65 percent of Java's population of around 138 million live in coastal regions (Kementerian Negara Lingkungan Hidup 2007) and is

2 Crude Migration Intensity (CMI) is calculated for a number of levels of spatial disaggregation, and computed by expressing the total number of internal migrants $(\mathrm{M})$ in a given time period as a percentage of the population at risk $(\mathrm{P})$ such that $\mathrm{CMI}=100 \mathrm{M} / \mathrm{P}$. 
therefore particular exposed to environmental change. The sheer size of the Indonesian archipelago ( 2 million $\mathrm{km}^{2}$ with over 18,000 islands) and its enormous diversity in terms of morphological, cultural and socio-economic characteristics translates into highly diverse patterns of population movement. Its history of large-scale migration within the country, both voluntary and regulated, is varied in terms of skill levels, destination and temporality. The various regional migration systems centre on the island of Java, but also focus on other growth poles such as the SIJORI triangle (a transnational development region, including the Indonesian Riau archipelago, Johor in Malaysia and Singapore), and North Sumatra and Southeast Kalimantan.

An analysis of interprovincial movement shows major population movements between the peripheral islands and Java and Bali. Still, there are also other significant population movements, both circular and more permanent, at the regional. For example, there is longstanding migration from Java, north and south Sumatra, and East Kalimantan linked to the estate economy and extractive industries (Spaan 1999). These regions also function as a transition corridor for international migration to Malaysia, Singapore, and further afield. In fact, analysis of recent migration patterns shows that migration levels at the inter-district level are higher in comparison to inter-island and inter-provincial levels for all age groups (Muhidin 2014: 326).

Although it is hard ascertain common patterns of population mobility, the environment, agro-ecological zones, and related economic activities are interrelated. Generally, the direction of migration is from the uplands and poorer islands in eastern Indonesia, areas which are generally arid, less fertile and lacking resources, towards the lower coastal areas and the islands of Java and Bali, with intensive farming and agro-industry. The bulk of industrial, public services, health, tourism, and education is located in urban agglomerations, many of which are situated along the coastline. The rapidly changing Indonesian workforce contributes to the urbanisation trend: as the proportion of primary school graduates in the workforce declines, over 50 percent of the total increase in 2002-2012 are secondary and tertiary graduates (due to successful educational policies in recent years). While agriculture still forms the bulk of labour demand (almost 40 percent in 2012), formal and informal non-farm employment account for around one third each (Manning/Purnagunawan 2014: 346). The major migration destination on the island of Java is the urban agglomeration around Jakarta (Jabodetabek). ${ }^{3}$

Although Indonesia has a long history of government migration policies aimed at population redistribution to relieve pressure on Java and Bali (e.g. the Transmigration program), data on interprovincial migration for the years between 1930 and 2000 indicates that economic factors were far more important than the resettlement programs (Van Lottum/Marks 2012).

The following sections introduce the two regional examples of Keta and Semarang. First, the respective socio-economic structure and the adopted development policies in the two regions will be highlighted. Next, the ongoing environmental

3 Jabodetabek is the acronym for the urban agglomeration around the capital, comprising Jakarta, Bogor, Depok, Tangerang and Bekasi with an estimated population of 30 million. 
changes will be discussed. Finally, the results of the empirical study concerning the demographic structure and migration pattern will be analysed in light of these changes.

\section{A Case study: Keta, Ghana ${ }^{4}$}

The first case study concerns a coastal area in the lower Volta region in southeastern Ghana. Keta town is located close to the mouth of the Volta river on the Gulf of Guinea. It lies on a sandspit between the Atlantic and Keta lagoon (see Fig 1). The agro-ecological zone is coastal savannah, characterised by poor soils, mangrove swamps and a bimodal rainfall pattern (approx. 700-800 mm/annum) (U.S. Forest Service 2011). Historically, the region was an important port of call for the trade in slaves, spices and gold, and important for fish processing (Akyeampong 2001). The population of Keta mainly lives off farming, fishing, salt and copra production and trade. The poverty incidence rate of the Keta region was between 40-50 percent in 2000 (Coulombe/Wodon 2007) and remains high. The Keta lagoon thus forms an important natural resource for food security, and is designated as a critical habitat for migratory birds and endangered marine turtles (U.S. Forest Service 2011). Keta is part of the Anlo-Ewe region, which has distinctive environmental, cultural and linguistic traits that stretch into the neighbouring Togo. Keta suffers from coastal erosion, loss of housing and declining lagoon fish stocks. The prominence of the market and trading function of Keta has faded and shifted to the city of Anloga in the same municipality, only $15 \mathrm{~km}$ southwest along the coast.

Ghanaian livelihoods, particularly of the poor in rural areas, are highly dependent on natural resources, which are currently under threat both by climate change and by non-sustainable human exploitation, resulting in erosion, deforestation, pollution and declining soil fertility and marine resources (U.S. Forest Service 2011). For the Volta river basin, a report warns that due to climate change impacts (i.e. higher temperatures and less, more erratic rainfall), river flow will decrease significantly, jeopardising food production, animal husbandry and hydro-power production in the Volta river watershed. In particular, the predicted greater variance in water availabil-

4 A total of 274 households were included into the sample, for a total of 1.345 people. The interviews were conducted in selected villages and towns suffering ongoing rapid environmental change. Households within these villages were selected by random sampling supported by GIS techniques: Afiadenyigba $(n=49)$, Anloga $(n=49)$, Blekusu $(n=24)$, Genui $(n=24), \operatorname{Kedzi}(n=25)$, Keta Town $(n=48)$, Tegbi $(n=50)$, N.N. $(n=5)$. Six Ewe-speaking interviewers conducted the survey in early 2015. Keta had 58 percent male-headed and 42 percent female-headed households, and a 47 percent male and 53 percent female population overall. Additionally, 95 experts, key informants, and migrants were interviewed. For the purpose of this study, we defined "migrants" as persons who leave their household for more than three consecutive months in order to live in another sub-district or community of Keta. The respondents were the household heads, who were asked about all household members who once used to live in the household and then moved away for more than three consecutive months. The qualitative data were gathered through semi-structured interviews with migrant households from Keta in Accra and Togo, two destinations of migration from Keta. Further key informant interviews with traditional and state authorities in Keta added to our knowledge base. 
Fig. 1: The Location of the case-study, Keta (Ghana)

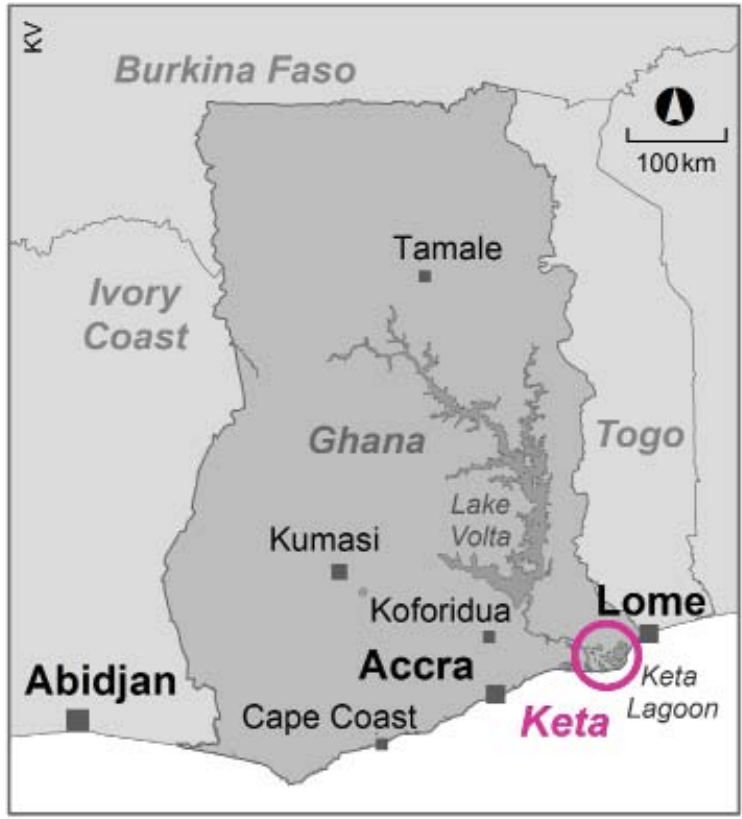

Source: Kartenwerkstatt TU Berlin, 2017

ity and lower groundwater recharge will have a detrimental impact on the rain-fed and irrigated agriculture common in the area. In Keta district, erosion, floods, tidal waves and wind storms have been reported in recent years. The coast has seriously eroded and the many houses that are permanently inundated pose great obstacles to (traditional) seine fishing. The following anthropogenic environmental hazards in the Volta basin including Keta coastal area have occurred: bush fires, depletion of fish stocks and clam beds (Torvikey 2014), groundwater pollution and silting of lagoon and rivers due to farming activity and deleterious fishing practices (e.g. use of agro-chemicals and TNT). Furthermore, groundwater depletion due to groundwater extraction for the salt-winning industry is common, in turn ruining local coconut groves.

Regional development policies emphasized industrialisation and large-scale infrastructure projects. In the 1960s, a hydroelectric power dam at Akosombo in the Upper Volta Region was constructed, followed by the smaller Kpong dam downstream, completed in 1982. In 2013, the Bui Dam came into operation. The development of hydro-electric dams has both positive and negative consequences. Power generation, industrial output (e.g. aluminium) and growth of economically vibrant urban centres such as Tema and Akosombo, and employment growth in the form of lakeside fishing count among the positives. The construction also lead to decreases in diseases such as river blindness and sleeping sickness due to the flooding of the breeding grounds of disease vectors, i.e. black flies and tsetse flies (Tsikata 2006). 
The downside is the inundation of villages, farms, burial and religious sites, forced resettlement and social disruption. ${ }^{5}$ The dams have contributed to the loss of forest, drastic changes in fish stocks downstream due to changes in water temperature and turbidity, coastal erosion and a silting of the estuary (Akyeampong 2001). The lower water levels due to dam construction upriver have resulted in the drying up of creeks, droughts and the emergence of pests (e.g. Cape St. Paul Wilt disease), negatively affecting downstream flora and copra production. The process of beach sedimentation along the coast has been disrupted due to dam construction, threatening the habitat of locals. ${ }^{6}$ Livelihoods are seriously affected by the loss of arable land, forest resources and the disappearance of creek and clam fishing, the latter traditionally being a major activity for local women. Moreover, an increase in the incidence of bilharzia and malaria has occurred due to slowing down of the river and through cross-infection via migrating Ewe and Ada fishermen and -women from endemic areas in lower Volta (Akyeampong 2001; Tsikata 2006).

Although Ghana has signed various conventions on environment, wildlife conservation, and climate change, and formulated policies on sustainable development, there is no specific policy on the coastal zone (Am/alo 2006; Boateng 2006). The failures and political difficulties involved in addressing the longstanding environmental problems of the Anlo-Ewe region including Keta are well documented (Akyeampong 2001). Locals have expressed their discontent with the fact that development efforts were mainly aimed towards the regions west of the Volta, as exemplified by the construction of the harbour and industries at Tema, giving a final blow to Keta's former harbour function. Despite the serious damage to Keta's housing and infrastructure caused by erosion throughout the years, and after several failed coastline protection attempts since 1960, it was only in 1998 that the large-scale Keta Sea Defense started being planned (see Fig. 2).

The project involved the construction of a sea wall, beach stabilisation (e.g. groynes; concrete block revetment), causeways, land reclamation and flood control structures. The $\$ 90$ million project is justified by the government not only as a means of protection for Ghanaian citizens, but also as securing local industry, fishery, commerce and promoting (eco-) tourism. ${ }^{7}$ However, sea defense measures have failed in some cases due to inadequate design and construction (Coastal Research Center 2013). Secondary effects such as downstream erosion had initially not been considered, but have emerged are a result of the sea defense construction works, according to local experts. Local inhabitants had to be resettled to newly built communities near Kedzi to the east of Keta town.

5 The Akosombo Dam alone led to the inundation of an estimated 4 percent ( 3275 sq. miles) of Ghana's land mass (Jopp 1965) and the resettlement of 80,000 people from 739 villages (Yaro et al. 2011).

6 Climate Change Threatens Ghana's coast. Al Jazeera, 28 Dec 2013, at: http://www.aljazeera. com/indepth/features/2013/12/climate-change-threatens-ghana-coast-2013129114224783683. html.

7 In Ada Foah, along the Volta southwest of Keta, another 160 million Euro sea defense project is built, with the aims of shoreline stabilisation, flood control, and increasing tourism potential (a sea turtle breeding site). 
Fig. 2: The sea defence in Keta Town

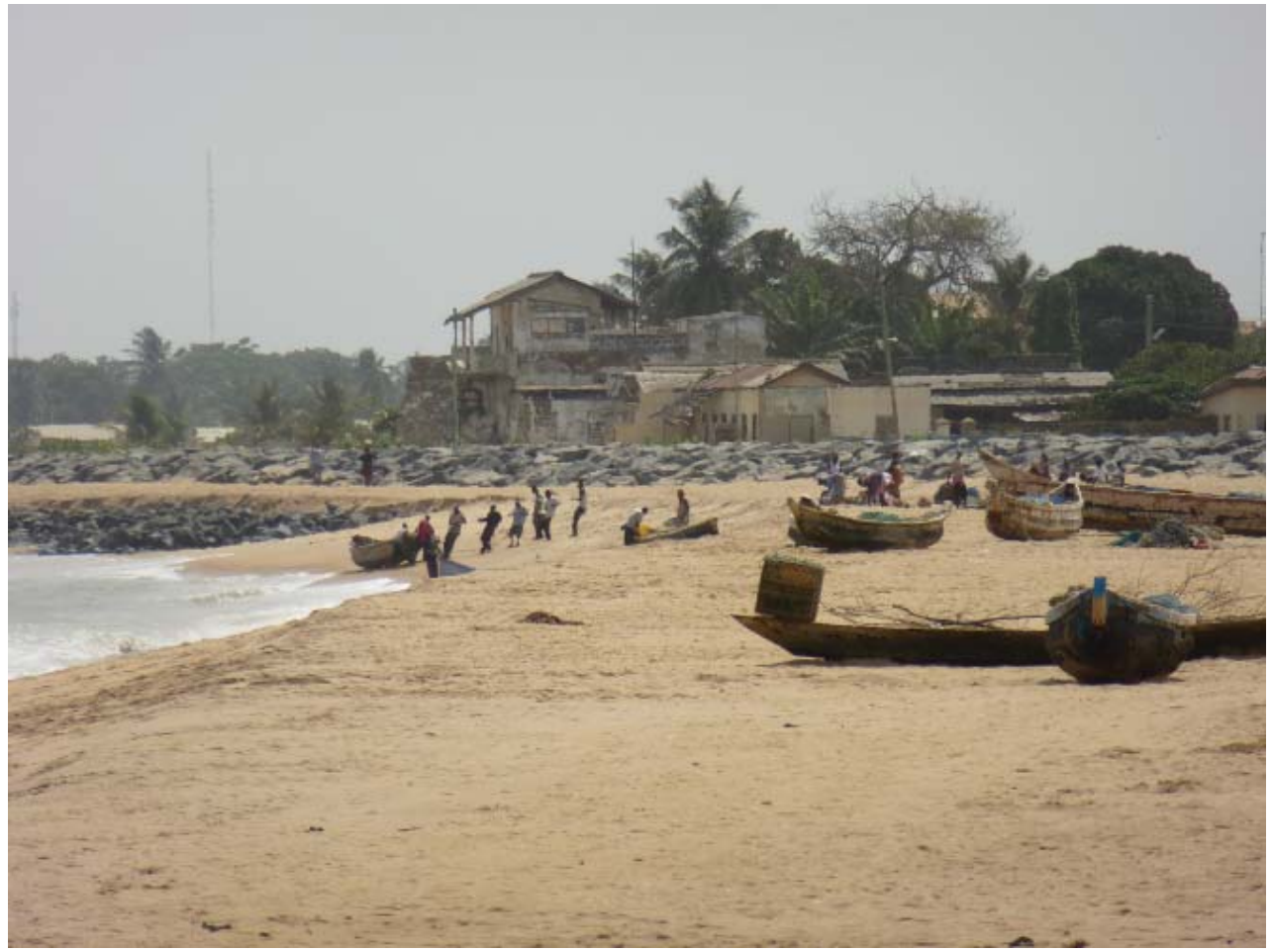

Source: photo by F. Hillmann, 2014

More recently, the discovery of oil deposits around the Keta lagoon is expected to have a significant impact on local economic activities, as it would affect offshore fisheries and the natural environment. Local development plans include petrochemical and cement plants, for which government land reclamation around the lagoon has taken place. Moreover, a canal is planned to be dredged between Keta lagoon and the Volta river estuary to facilitate transport, trade, and tourism. These activities are expected to boost the economy and employment, but they could also be detrimental to the environment and local fishery industry.

The population of Keta has shrunk since 1960, but increased slightly between 2000 and 2010. Whereas the population stood at 16,719 in 1960, it declined to 14,446 in 1970 (-14 percent), 12,595 in 1984 (-13 percent) and 8,101 in 2000 (-36 percent) (Yaro et al. 2011: 37-38; based on population census data). Despite the declining economic importance of Keta, there is still limited (seasonal) in-migration from neighbouring regions for education and work in fishing, trade and construction. Nevertheless, the Keta area is mainly an area of out-migration, as our respondents stated. In large part, migration consists of seasonal movements, varying from several months to a few years, e.g. for fishing or trade, whereby people move upstream and to other coastal cities. Many also venture abroad to destinations in West Africa, mainly Ivory Coast (Abidjan) and Togo (Lomé). Local fishermen temporarily 
move along the coast as far away as Sierra Leone and even Angola: "you see the fishermen migrating with the fish" (interview partner). Interviews with fishermen and local experts made it clear that this mobility was necessitated by diminishing catches along the coastline due to overfishing by European and Chinese trawlers and because of the insufficient meshes used by many local fishermen. Women, who traditionally sell the fish at the market, complain that the changes in Keta started a vicious cycle of downgrading, producing out-migration. As one of our interview partners states

"In the event that men do not get fish, it implies that they were not going
to get money to fend for the family. It is this same fish that we women
also buy to smoke and sell, so we are also not able to raise money even
if we get the fishes to smoke and there is no one to buy them. When the
fishes are not sold, we are as well unable to pay the men and thus the
situation affects almost anybody". (Interview 26, market woman)

The notion of mobility is deeply rooted in the regional tradition of the Anlo-Ewe. A migration saga, related to the Ewe-Anlo fishermen, is kept alive and is still recited by the local population (Kumassah 2009). Today, the Hogbetsoso festival, which commemorates the exodus of the Anlos from Notisie in the Republic of Togo, is celebrated annually. The saga exemplifies the mobility that was vital to the life of the Anlo people over the centuries.

Indeed, our survey revealed a highly mobile population. A quarter of all households reported to have one or two circular migrants (mostly moving to Accra) staying away less than half a year. Only a tiny share of households, 5 percent, reported to have members that stayed away for more than two years. Circular migration was directed mainly, 68 percent, towards (Greater) Accra and the Keta lagoon. Return migrants, defined as persons who lived away for more than three consecutive months during the past five years, lived in 27 percent of the interviewed households. When asked about the professional status of the household-heads, 21 percent said to own a business, 16 percent were artisans, another 16 percent fishermen and 15 percent were retired. The majority, 56 percent, owned the land on which they lived. The results of the survey point out that out-migration was mainly directed towards Accra, in 71 percent of all cases, while some, 8 percent, ventured to neighbouring African countries such as Benin, Nigeria and Togo. Very few also migrated to Europe and the US via Accra. Half of the interviewed migrants said to have received assistance for their migration, mostly money from other householdmembers. No agencies - as often the case in international migration - were used to facilitate the migration. For many households having a member abroad meant an additional source of income and thus a net reduction in risk. About one third (30 percent) of all interviewed households said that they received remittances from migrated household members, generally between 100 to $499 \mathrm{Cedi}^{8}$ per year (contributing to an average income of around 4.000 Cedi per year). About 7 percent of

8100 Ghanaian Cedi are equivalent to $\$ 31$ (January 2015). Fisherman earn around 2 Cedi a day, the minimum wage is 5 or 6 Cedis a day (interview 21, 2014). 
these migrants provided food for the household. Out of the 583 migrants in the sample, men made up 53 percent. Most migrated at the ages of 10-29, elder people moved only rarely. 58 percent of the migrants stated that they went away for work. Much of the migration, 24 percent, was due to educational aspirations, a tenth to family reasons. Indeed, apart from secondary schools, the region offers very few tertiary institutions, and none of them offer training for local employment. As one of our interviewees claims:

"What you are trained with, you cannot be employed here, you can only be employed outside. That is why many of us who are literate must go elsewhere for employment [...] So, everybody who wants to further their education must move out [...]".

Environmental change had an impact on livelihoods. Only a small share of our respondents $(0,7$ percent) said that they moved due to environmental reasons, despite the fact that 167 households out of 288,60 percent, said to have experienced damage to the personal property or health through extreme environmental events. According to our data, migrants could count on support for their migration from other household members, relatives and migrated relatives. Priests and local chiefs had a limited say in the decision to migrate for most of our respondents.

Our sample showed a rather positive attitude towards migration: 59 percent of all respondents said that migrants could come back even if they fail in making a living elsewhere, 64 percent thought that households with a migrant are better off than those without, 53 percent of respondents said that they were in favour of going away. Family ties turned out to play an important role for migration decisions, as half of all interviewees stated that children should ask their parents before moving away. There is clearly a cultural obligation to take care of one's parents.

In Keta, as in some other places in the Volta region, out-migration has produced a relatively new phenomenon of socio-economic organisation. In addition to the common way of choosing chiefs from specific families or clans, a second category of chiefs is now selected on the basis of their resources to help develop the region, resulting in a new group of "development chiefs". A local chief points out:

"But now for prestige's sake, first of all the chief can be anybody whether educated or not, but now they want an educated chief, especially when the person is rich and they think he/she can help in terms of development. So, these chiefs are called development chiefs".

Traditionally elected chiefs might also reside outside Keta and still be involved in local policies and development. A main goal is to secure connections to NGOs and to increase the contact with ministers to elicit help. Diaspora associations such as the Council of Ewe Associations of North America (CEANA) also engage in local politics. A member of the association explains this process as follows:

"And currently we help a school, also in the Volta region. Some of our colleagues went to Ghana and went to the school and saw how the condition was and they came and did a presentation and the association 
decided to help out. They decided to do some fundraising, some books and coins, and then we started also with fellowships for pupils".

This help was widely accepted by the resident population and was also mentioned by the diaspora interview partners.

The outcome of our research on the articulation of migration and population dynamics in the local setting of Keta (which is repeatedly flooded) points to migration as having emerged as part of an increase in urbanisation, rather than due to the challenges of environmental change themselves. The local population is well aware of the dangers of environmental change, but the overexploitation of resources (fishing), the downgrading of the market and trading functions, and the better education opportunities in the urban centres have a far greater impact on their lives. Most mobility is still internal, but migration to the urban hubs, to neighbouring countries, and to Europe and the US is a well-known form of mobility. Overall, migrants abroad and the long-term diaspora contribute to local development.

\section{B Case-study: Semarang regency and city, Indonesia ${ }^{9}$}

The second example presented here is the town of Semarang (Kota Semarang), a regency (Kabupaten) on the north coast of Central Java, Indonesia. The total population of Central Java was 32.6 million in 2012, up from 31.2 million in 2000 (BPS 2014). The region is already highly urbanised, and increasingly so: the urbanisation rate was 40.4 percent in $2000,56.2$ percent in 2010 and is projected to grow to 73.8 percent in 2025 (Indonesian Statistical Bureau, 31 May 2010). Central Java is traditionally a region of out-migration.

The Semarang Metropolitan Area (SMA), also called "Kedung Sepur," is designated as one of Indonesia's national strategic growth areas (MP3EI 2011), and consists of the cities of Semarang, Salatiga and Purwodadi and four adjacent districts (Kendal, Demak, Ungaran, Grobogan), with a population of around 5.4 million people (in 2010). Semarang city proper, as a major sea port, transportation hub, and important industrial, service, and manufacturing centre with aquaculture

9 A total of 334 households has been included into the sample, portraying a total of 1.417 people, 265 outmigrants and 129 inmigrants. The interviews were done in selected kecamatan sub-districts)which suffer ongoing rapid environmental change, especially flooding, in Semarang (in Tugu, Semarang Berat, Semarang Utara, Semarang Timur, Genuk, Semarang Tengah, Tembalang), Households have been selected by random sampling and have been supported by GIS-techniques. The sample was carried out in the months November/December 2014. The respondents were composed as follows: 82 percent male-headed, 18 percent female-headed households representing 1,417 household members (48 percent male, 52 percent female). For the purpose of this study we defined "migrants" as persons who leave their household for more than three consecutive months in order to live in another place, at least another sub-district (Ind.: Kecamatan) of Semarang City or another Municipality respectively or further away. The respondents in the survey were the household heads who were asked about all household members who once used to live in the household and then moved away for more than three consecutive months. Additionally, 92 experts, key-informants and migrants were interviewed. In Semarang the qualitative interviews consisted of key informant interviews with heads of villages and sub-districts in Semarang Municipality. 
(fish, shrimp farms) and agro-industry, forms the core of the Kedungsepur regional growth pole, linking the city with the urban and rural economies in the hinterland, including timber, textiles and foodstuff production. In the late 1990s, Semarang Port added a container wharf to be able to handle the rapidly increasing volume of container cargo. In the past years, the regional distinction between rural and urban is becoming blurred, as Semarang is becoming increasingly linked to Yogyakarta on the southern coast of Central Java via an urban corridor.

Semarang city itself had a population of 1.5 million in 2011 (BAPPEDA BPS Kota Semarang 2012), with a population density of 23,000 people per $\mathrm{km}^{2}$ (Mulyana et al. 2013) stretching over approx. $374 \mathrm{~km}^{2}$ (see Fig. 3). Semarang's population includes a significant proportion of ethnic Chinese and Arabs (Suryadinata et al. 2003), a reflection of the city's history as a major port and international trading centre, with strong linkages to the outer islands and abroad. The territory is divided into three morphologically distinct zones: a lowland area (zero to 3.5 metres above sea level) in the north, a plain zone with higher elevation (3.5-90 metres) and a highland area (90-348 metres) (Hadipuro 2012). Although the largest part of the city is located on higher ground, the highest population concentrations are in the low-lying alluvial zone along the coast. About 30.000 people live in the coastal area of which many depend on agriculture (fishermen and farmers).

Fig. 3: The Location of the case-study, Semarang (Indonesia)

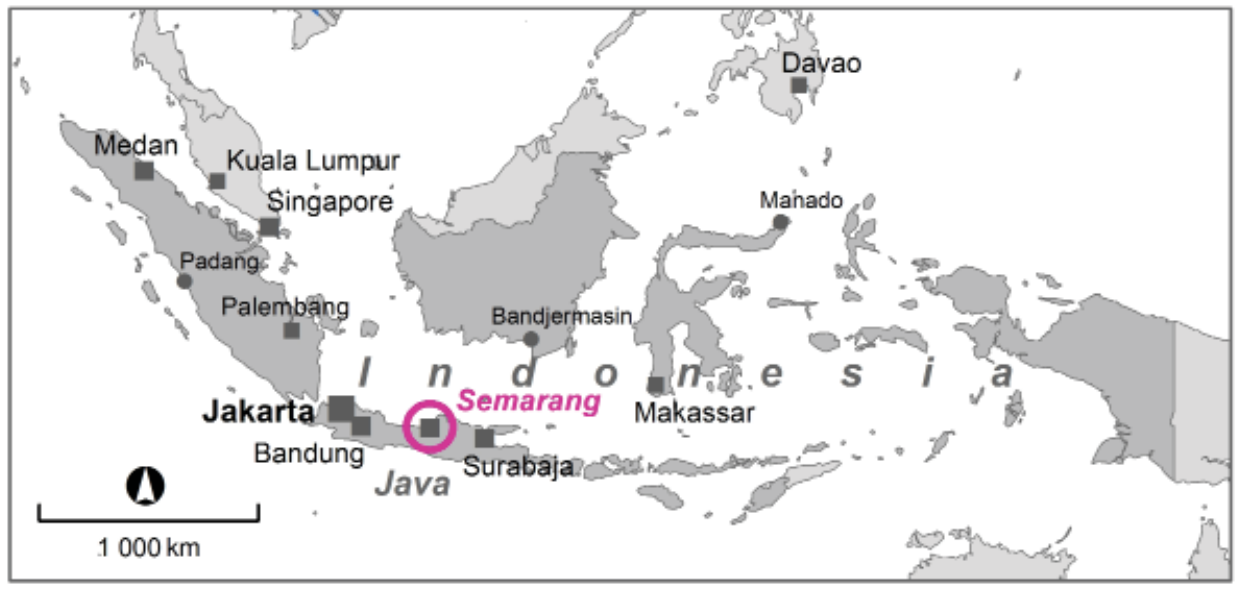

Source: Kartenwerkstatt TU Berlin 
Due to its location on the northern littoral, the population of Semarang is prone to environmental hazards. ${ }^{10}$ Beyond the low elevation along the coast, mangrove depletion, tidal processes, excessive groundwater extraction, and construction load, tidal inundation, erosion and water pollution are the main causes for land subsidence (Marfai et al. 2008; Marfai 2011; Hadipuro 2012). Land subsidence in Semarang is nurtured by rapid urbanisation and the conversion of land into industrial and residential areas, a process that has been ongoing for decades. However, problems of soil erosion, downstream sedimentation and flooding in the lower watersheds are also the result of forest management policies in the highlands (logging; conversion of teak forests to pine production forests; Paripurno 2006). Furthermore, Semarang is experiencing changes in average surface temperatures and precipitation patterns, shifts in wet and dry seasons, and increased frequencies of extreme weather events such as droughts and intense rainfall (CCROM, cited in Mulyana et al. 2013). The city also suffers from rain floods. This flooding is exacerbated by sand mining and housing development in the highlands, as well as the poor sewerage and waste management systems in the city (Hadipuro 2012). Semarang was included in the Rockefeller Foundation's "100 Resilient Cities" program, and has undergone a variety of adaptation and mitigation measures. ${ }^{11}$ Among the most conspicuous adaptation strategies are the introduction of an Early Warning System in 2012, and the now widely acknowledged initiatives to replant mangroves near fishponds (Yuniartanti et al. 2016 ). To prevent flooding caused by sea-level rise, the erection of a "giant sea wall" on the northern coast is planned for 2017 - meaning that fishermen no longer would be able to fish in the shallow waters along the coastline.

The above-mentioned mixture of environmental conditions has significant detrimental consequences for local livelihoods, the community's social fabric, and population health. Populations in coastal areas and slum dwellers without well-built housing and proper sanitation facilities are particularly vulnerable. However, Mulyana (Mulyana et al. 2013) indicates that high-risk areas do not necessarily house poor residents with impermanent housing. It is the level of vulnerability and capacity to successfully employ coping mechanisms that counts rather than income level per se (Mulyana et al. 2013). ${ }^{12}$

10 Mulyana et al. (2013: 13ff.) identify the following areas as particularly vulnerable in the face of environmental change: the lowland regions, which are exposed to coastal flooding and sea level rise; settlement areas located in riverbeds, which are exposed to tidal and flash flooding; hilly areas, which are exposed to high winds; and areas that are exposed to land movement and landslides.

11 The Adaptation strategies promoted throughout the Resilient Cities program included a Coastal area climate information system with the purpose to increase resilience. Further, Community groups in coastal Semarang replanted mangroves to stabilise the fishponds and strengthen the seaboard. New forms of ecotourism (often addressing high schools) were initiated next to fish cultivation (milkfish and shrimp). Fish-cracker (krupuk) production by women's groups were set-up as part of resilience measures.

12 The authors measure vulnerability with indices of hazard exposure, population indicators (e.g. population density, dependency ratios) and household indicators (e.g. secure tenure index, quality of housing amenities). 
One might expect that these precarious circumstances would lead to high(er) rates of out-migration in frequently flooded areas. However, the Semarang agglomeration is an area of in-migration. Of the six major kota (municipalities) in Central Java (Magelang, Pekalongan, Surakarta, Salatiga, Semarang and Tegal), only Semarang recorded positive net lifetime migration (261.183) in the 2010 census; recent migration was also only positive in Semarang (59.333) (BPS 2012). Semarang regency, however, had a negative net migration (-274.229). Semarang remains an important pole of attraction for people from all over Indonesia seeking education and employment in the metro area. The population of the city of Semarang is gradually increasing due to natural population growth and in-migration. The net migration rate of Semarang was 2.24 in 2011; with the in-migration rate being 28.44 and the out-migration rate 26.21 (BPS 2014). Authors such as Handayani et al. (2015) point to a substantial share of undocumented in-migration. Sub-districts that have net out-migration rates in 2011 are Candisari, Gayamsari, Semarang Selatan, Timur, Utara, Tengah and Barat. These areas within the low-elevation coastal zone have high population densities and some suffer from environmental hazards such as flooding (Mulyana et al. 2013; BPS 2014).

How to explain the in-migration into the flooded areas? Our survey reveals a rather stable population in these districts. Indicators for this stability include the low share of return migrants, mainly spending time somewhere else in Java for 2-3 months, which was reported by only 6 percent of the respondents. Also, most in-migrants (54.3 percent) came to Semarang for family reasons, usually marriage. Nearly one third (30.7 percent) was seeking a job, and 10,2 percent said to have come for educational reasons.

Generally, migrants are more vulnerable as they are more likely to end up in areas with poorer housing and amenities. They often lack social support networks, making them less resilient to environmental hazards. However, our research in the low-income high-risk areas showed that the local population opted for local adaptation measures such as the strengthening and raising of houses, rather than moving away. Almost half (46 percent) of our interview partners had already heightened their house, by about 1-2 meters every five years, on average (see Fig. 4). Furthermore, these areas turned out to be the destination for in-migrants, to which the inhabitants sometimes sub-rent. Poorer households either lacked the financial means for housing improvements and for financing migration. They are therefore locked down and completely dependent on local employment opportunities in manufacturing, (informal) services, trade and fishing. 75 percent of our survey respondents owned the house in which they lived, while only 5.4 percent rented the house they lived in. Some of the interviewees listed "attachment to place" as a reason for staying. Others alluded to the distrust in the government when it comes to questions of compensation in case of resettlement. Informally, the relocation of population has been attempted in the past years, as the interviewed experts reported. In total, our sample portrayed a stable population in the different Keluharan, most having lived there for more than a generation. Immobility is nearly synonymous with missing opportunities, and as an expert puts it, "the lights of the city shine brighter than the flooding". 
Here, resilience is the strategy of the poor who have no other place to go:

"People who stay in the coastal area are not wealthy people, they are used to the conditions of flooding, and they accept this living condition (...) we're poor so we have to enjoy this, if we don't want to experience this, we will have to wait until we are rich". (Interview Nr.49, UNDIP 29.07.2015)

Interestingly, 85 percent of all households interviewed see the environment as a major risk (compared to 25 percent mentioning disputes, conflicts and crime, and 7 percent mentioning their health). 40 percent have experienced floods (including tidal floods), and about 20 percent suffered damage to their houses. However, most respondents foresaw no threat of environmental change to their households in the coming year.

Fig. 4: The difference between the heightened house and the "sinking" house is evident, the community road has been renewed

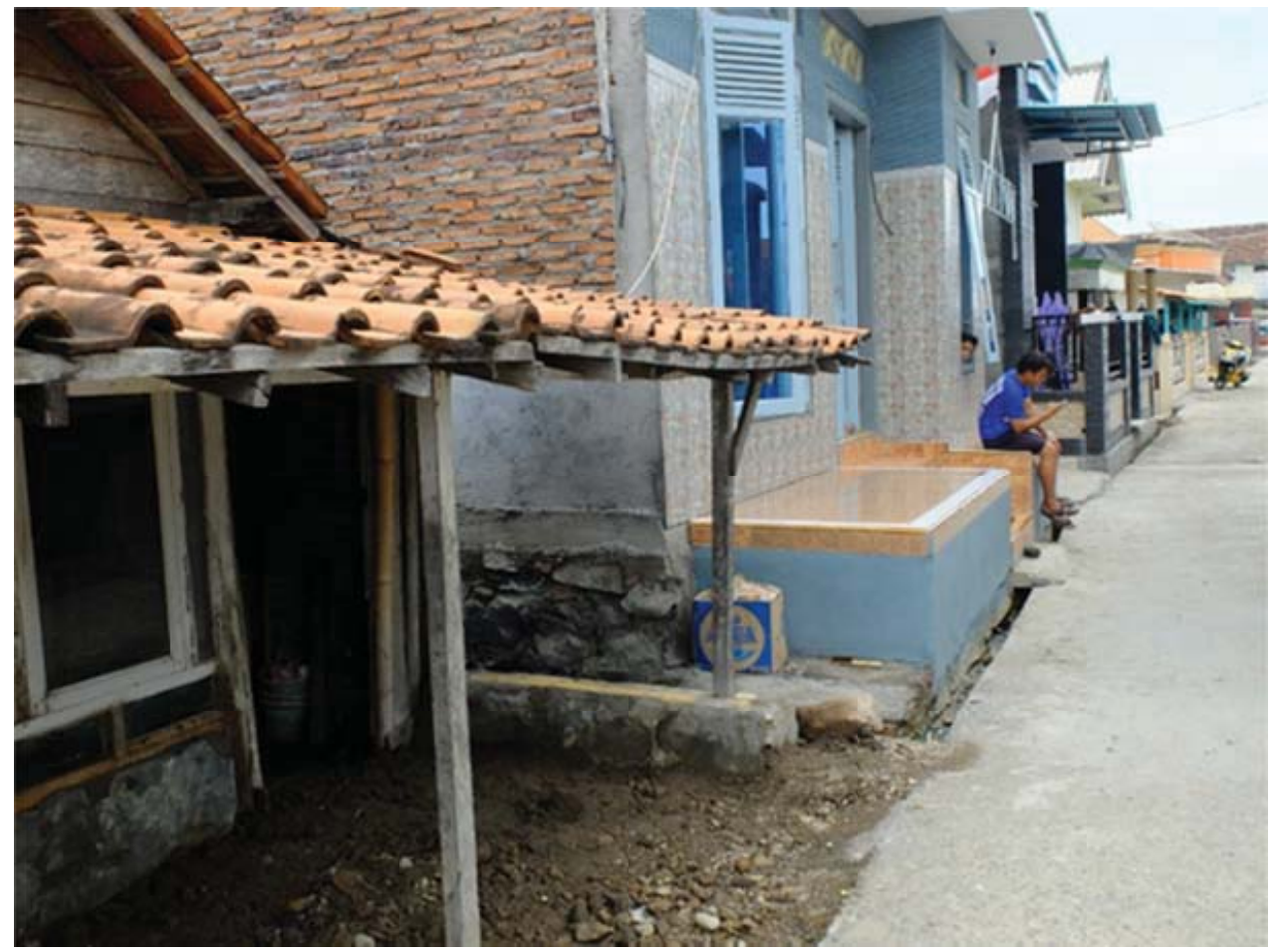

Source: Morodemak in Demak, neighboring Semarang, photo by F. Hillmann

Migration patterns mainly cover adjacent rural areas, with only under 2 percent of the Semarang population having lived outside Central Java within the past five years. Next to long-term migration to Semarang city from nearby regencies such as Grobogan, Demak, Kendal, there is significant lifetime migration from other urban centres in Central Java, e.g. Surakarta and Salatiga. The recent migrants to Sema- 
rang city are mainly young and single people, most of whom find employment in the service industry ( 80 percent) and manufacturing (19 percent), the latter mostly women (BPS 2012).

Our survey confirms this pattern: the usual origin of the in-migrants was Java, which was also the most common destination of the out-migrants. Recent migrants in Kabupaten Semarang are mainly employed in manufacturing, young women often work in the textile industries. Semarang has lower wages then Jakarta, which has brought manufacturing to the town. Living conditions in the neighbouring rural areas are harsh and do not guarantee a stable income. This is what a fisherman had to say about his motivation to move away from Morodemak, an eastern fishing village:

"The difference here [compared to the city] is that people just work in the sea. So if we can't go fishing [because of extreme weather events], we get no money. In the city it is different. You can go every day to work and get money every day. That's why people from here migrate. The work in the sea is hard! With rain, wind and waves". (Gerstenberg 2015: 64)

One important aspect of migration trajectories are the narratives on migration. In Semarang, the perceptions of migration by the respondents are rather ambiguous: 49 percent perceived migration as negative and stated that "you should never leave your place of origin." Less than a half of our sample, 45 percent, see no further benefits for the household in the migration of household members. This hints to the fact that the migration of one household member is not seen as a major strategy to improve the situation of the entire household. However, 60 percent agreed that migration brings benefits for the community. Our data clearly shows respondents prefer domestic migration to leaving the country, with 68 percent of respondents answering that it would be "better to migrate within Indonesia than to go abroad."

In our sample from Kota Semarang, we found only a tiny share of international migrants - even though Semarang is an international and ethnically diverse city and a longstanding trading tradition. Only one-tenth of all households received remittances: 1-20 Million IDR per year on average in 2015 (the average household income was 500.000 Ind per month ${ }^{13}$ ). In more than half of all cases, the out-migrants did not contribute to the household income or they only contributed on a monthly basis. Telephone and SMS (texting) are the main tools of communication, email and Skype are uncommon, and social media such as Facebook are used only sparsely. The perception of migration was fairly negative: again, 49 percent of our sample agreed with the statement that "you should never leave your place of origin." About half of the households in our sample did not think a household benefits from migrated family members. On the contrary, 52 percent believed that migration causes inequality and conflict within the community.

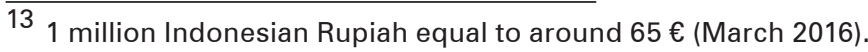


So, considering that the living conditions in rural areas tend to deteriorate and given that the city still offers a range of opportunities, Semarang remains attractive for in-migrants, despite its environmental challenges.

\section{Conclusion}

Two of the current contentious issues among academics, policymakers and the general public are climate change and the related trends in migration. Jointly, the two phenomena have led to heated debates and produced alarmist images of large population displacements due to natural disasters and severe environmental degradation. However, causality is not straightforward and the meagre evidence is still rather mixed as to how climate change influences human mobility. Thus, as we argue that the multi-dimensional character of migration must be acknowledged and that more in-depth analysis must consider other, perhaps more important, drivers of migration; including socio-cultural aspects, economic development, and historical migration patterns as well as related narratives and belief systems. Research on these linkages would benefit from analysis employing a regional focus which takes into account the specificities of regionally rooted socio-economic configurations, demographic developments, livelihoods, and governance structures.

Focusing on two coastal regions in Ghana and Indonesia which the IPCC considers highly vulnerable to climate change impacts and the ensuing population mobility, our contribution serves to illustrate the regional embeddedness of migration patterns, but also that changes in local climate and environment - although significant - do not necessarily cause large scale and international migration.

Although our two case studies are from very different regions, they do show some commonalities in terms of environmental problems, human mobility, and historical development patterns. In both regions, anthropogenic environmental problems are prominent and a result of unsustainable economic development policies, such as the destruction of mangroves in favour of setting up fishponds, large scale infrastructural and industrial development along the coast, deforestation, and the building of hydro-electric power plants in the hinterland. Longstanding technical adaptation measures such as drainage systems (Semarang), the construction of wave breakers and moles (Keta and Semarang), and even dams (Keta) have changed the sedimentary structure and make it difficult to differentiate between man-made and "natural" environmental change today. In the case of Semarang, rapid urbanisation is the main driver for land subsidence and consequently the sinking of houses.

Despite severe environmental problems, the two case studies clearly show diverse migration patterns, both to and from the region. These mobility patterns are mainly driven by economic opportunities and educational possibilities, rather than by climate change. Semarang and Keta were prominent port cities in the past, but have seen their economic position decline as other major coastal cities emerge (Tema in Ghana; Jakarta and Surabaya on Java), partly due to their countries' development policies. Mobility in both case study regions is mainly within-country and largely to and from adjacent regions. Whereas Keta in Ghana has out-migration, 
fuelled by local environmental degradation, economic decline, and rapid economic development along the Accra-Tema corridor in Ghana, it also attracts some migrants from Volta and adjacent regions, for reasons of trade and education. International migration flows are relatively small, but include some traditional mobility along the coast by local Ewe fishermen and -women, traders from Ghana and neighbouring Togo, and outbound and return migration by higher educated workers venturing to Europe, the USA, and other developed countries. Furthermore, narratives such as the Anlo-Ewe migration saga are part of local traditions and are kept alive through festivals and an active diaspora through the sharing of local knowledge by chiefsand sub-chiefs. Our survey shows a population that is inclined to migrate and that actively fosters a culture of migration.

In comparison, Semarang city has attracted migrants for decades. The city remains an important administrative centre, major transportation hub, industrial and manufacturing centre, and boasts vital educational and health facilities and other public services. Thus, Semarang attracts many migrants, the bulk of whom come from adjacent rural areas seeking employment in local industry and the informal sector. International migration from Semarang is limited. The population in the flood-prone coastal areas is stable and adapts with in situ solutions such as the heightening of houses. Most respondents did not perceive migration as a privileged way of adaptation, but rather stressed that "attachment to place" is a virtue. Living conditions in the neighbouring districts such as Demak were even harsher than in the city and put additional pressure on the resident population.

As for detrimental environmental change and its impact on migration, the case studies show that migration patterns nowadays appear to be path-dependent and thus tend to be stable over time. Also, increasing education opportunities and economic growth, as well as urbanisation, seem to impact migration more than ongoing environmental change does. Concatenated crises, a cumulation of diverse shocks and disturbances, (Biggs et al. 2011) seem to be at core of the new mobility patterns. Climate change was addressed by policy-makers in both cases and became part of the cultural narrative, but was in fact not seen as a major threat by the local population. In Semarang, although some movement away from the low-lying coastal areas prone to land subsidence and flooding is underway, a large proportion of the population adapts to these environmental threats and continues seeking a livelihood in situ. The case of Semarang shows that vulnerability exists precisely because of the immobility of the resident population. Many are poor and cannot afford to leave, as they lack resources and seek job security with the local employment opportunities.

Both local governmental development policies and environmental policies are rather technical, emphasizing large scale coastal protection measures, and both sustain the sedentarism of local populations.

We conclude that although the environmental phenomena in question - flooding and erosion - may seem similar, they can have very different effects on population mobility as is evident from the contrasting case studies presented here. Only an analysis rooted in the regional setting allows for the identification of socio-economic, cultural, environmental and historical legacies that determine migration and population dynamics. Further, argumentation that refers on assumptions that are 
based on global data and trends, will remain blind for what can be done to ease the situation for the many people that are confronted with a changing environment on the local level. Population movements occur mostly on the regional scale and thus the needed innovative approaches to tackle the situation are likely to be of integrative nature - combining social, economic, ecological and migration-related action.

\section{References}

Afifi, Tamer; Warner, Koko 2008: The Impact of Environmental Degradation on Migration Flows across Countries. Working Paper 5/2008. Bonn: United Nations University - Institute for Environment and Human Security.

Akyeampong, Emmanuel K. 2001: Between the Sea and the Lagoon. An Eco-social History of the Anlo of Southeastern Ghana, C. 1850 to Recent Times. Athens: Ohio University Press/Oxford: James Currey Publishers.

Amlalo, Daniel 2006: The Protection, Management and Development of the Marine and Coastal Environment of Ghana. In: Administering Marine Spaces: International Issues. Copenhagen: International Federation of Surveyors (FIG Commissions 4 \& 7 Working Group 4.3). FIG Publication 36: 148-157.

Anyangwe, Stella C. E.; Mtonga, Chpayeni 2007: Inequities in the Global Health Workforce: The Greatest Impediment to Health in Sub-Saharan Africa. In: International Journal of Environmental Research and Public Health 4,2: 93-100 [doi: 10.3390/ijerph2007040002].

Arnold, Nicola 2014: Analysis of the drivers of forest degradation and deforestation in Worobong South forest reserve in Eastern Region, Ghana - A Case study on migrant and non-migrant households in the fringe community Ahomahomasu. Master Thesis. Free University of Berlin.

Awumbila, Mariama; Ardayfio-Schandorf, Elizabeth 2008: Gendered poverty, migration and livelihood strategies of female porters in Accra, Ghana. In: Norsk Geografisk Tidsskrift - Norwegian Journal of Geography 62,3: New Faces of Poverty in Ghana: 171-179 [doi: 10.1080/00291950802335772]

Black, Richard 1998: Refugees, Environment and Development. London: Longman Development Studies.

BPS (Badan Pusat Statistik) 2012: Statistik Migrasi Jawa Tengah. Hasil Sensus Penduduk 2010.

BPS (Badan Pusat Statistik) 2014: Proyeksi Penduduk [URL: http://www.datastatistikindonesia.com/proyeksi/index.php?option=com_proyeksi\&task=show\&ltemid=941, 10.6.2014].

BPS (Badan Pusat Statistik Kota Semarang) 2014: Semarang Dalam Angka [URL: http:// semarangkota.bps.go.id/index.php/en/keadaan-geografi, 10.6.2014].

BAPPEDA BPS Kota Semarang 2012: Profil Kependudukan Kota Semarang 2011. Semarang: Bappeda Kota Semarang/Piro Pusat Statistik Kota Semarang.

Biggs, Duan et al. 2011: Are we entering an era of concatenated global crises? In: Ecology and Society 16,2: 27.

Bleibaum, Frauke 2010: Case Study Senegal: Environmental Degradation and Forced Migration. In: Afifi, Tamer; Jäger, Jill (Eds.): Environment, Forced Migration and Social Vulnerability. Berlin/Heidelberg: Springer-Verlag: 187-196. 
Boateng, Isaac 2006: Institutional Frameworks in the Administration of Coastal and Marine Space in Africa. In: Administering Marine Spaces: International Issues. Copenhagen: International Federation of Surveyors (FIG Commissions 4 \& 7 Working Group 4.3). FIG Publication 36: 102-118.

Castles, Stephen 2002: Environmental change and forced migration: making sense of the debate. New Issues in Refugee Research - Working Paper 70. Geneva: United Nations High Commissioner for Refugees.

Coastal Research Center 2013: Coastal Hazards and Flooding Risk in Ghana's Western Region. In: Hen Mpoano: Our Coast, Our Future. Issue Brief 7. Narragansett, RI: Coastal Resources Center, Graduate School of Oceanography, University of Rhode Island. USAID Integrated Coastal and Fisheries Governance Program for the Western Region of Ghana.

Coulombe, Harold; Wodon, Quentin 2007: Combining census and household survey data for better targeting: The West and Central Africa Poverty Mapping Initiative. Poverty Data, Measurement and Policy. Special Expanded Edition. Washington: World Bank.

El-Hinnawi, Essam 1985: Environmental Refugees. Nairobi: United Nations Environment Programme.

Findlay, Allan; Geddes, Alistair 2011: Critical views on the relationship between climate change and migration: some insights from the experience of Bangladesh. In: PéCoud, Antoine; Piguet, Etienne (Eds.): Migration and climate change. Cambridge: Cambridge University Press: 138-159.

Ghana Statistical Service 2012: 2010 Population and Housing Census. Summary Report of Final Results. Accra: Ghana Statistical Service.

Gerstenberg, Annika 2015: Vulnerability of households and adaptive responses to changing environmental conditions. A case study in the rural coastal area of Central Java, Indonesia. Master Thesis. Free University of Berlin.

Glaeser, Bernhard; Glaser, Marion 2010: Global change and coastal threats: The Indonesian case. An attempt in multi-level social-ecological research. In: Human Ecology Review 17,2: 135-147.

Hadipuro, Wijanto 2012: Water Supply and Urban Livelihoods. Case study in Semarang, Indonesia. Dissertation. Nijmegen: Radboud University Nijmegen.

Handayani, Wiwandari; Kumalasari, Novia R. 2015: Migration as Future Adaptive Capacity: The Case of Java - Indonesia. In: Hillmann, Felicitas et al. (Eds.): Environmental Change, Adaption and Migration. Bringing in the Region. Basingstoke: Macmillan/Palgrave: 117-140.

Hansen, Christian P.; Lund, Jens, F.; Treue, Thorsten 2009: Neither fast, nor easy: the prospect of Reducing Emissions from Deforestation and Degradation (REDD) in Ghana. In: International Forestry Review 11,4: 439-455.

Herbeck, Johannes 2015: Climate Mobilities from a Human Geography Perspective: Considering the Spatial Dimensions of Climate Change. In: Hillmann et al. (Eds.): Environmental Change, Adaptation and Migration. Bringing in the Region. Basingstoke: Palgrave/Macmillan: 21-39.

Hill, Harvey; Wiener, John; Warner, Koko 2011: From fatalism to resilience: Reducing disaster impacts through systematic investments. In: Disasters 36,2: 175-94 [doi: 10.1111/j.1467-7717.2011.01256.x].

Hillmann, Felicitas; Kronauer, Lisa 2010: Klima und Migration. Eine Systematisierung des Wissensfeldes. Bremen: Universität Bremen, Institut für Geographie. 
Hillmann, Felicitas et al. 2015: Introduction. (Re-)locating the Nexus of Migration, Environmental Change and Adaption. In: Hillmann, Felicitas et al. (Eds.): Environmental Change, Adaptation and Migration. Bringing in the Region. Basingstoke: Macmillan/ Palgrave: 1-17.

Hugo, Graeme 1996: Environmental Concerns and International Migration. In: The International Migration Review 30, Special Issue: 105-131 [doi: 10.2307/2547462].

Hugo, Graeme (Ed.) 2013: Migration and Climate Change. Cheltenham, UK: Edward EIgar Publishing.

Indrarto, Giorgio B. et al. 2012: The context of REDD+ in Indonesia. Drivers, agents and institutions. CIFOR Working Paper 92. Bogor: Center for International Forestry Research (CIFOR).

IPCC 2014 [Field, Christopher B. et al. (Eds.)]: Climate Change 2014: Impacts, Adaptation, and Vulnerability. Part A: Global and Sectoral Aspects. Contribution of Working Group II to the Fifth Assessment Report of the Intergovernmental Panel on Climate Change. Cambridge, UK/New York, USA: University Press Cambridge.

Jopp, Keith 1965: Volta: the story of Ghana's Volta River Project. Accra: Volta River Authority.

Kementerian Negara Lingkungan Hidup 2007: Rencana Aksi Nasional dalam menghadapi Perubahan Iklim.

KNOMAD 2015: Longitudinal Research on Environmental Change and Migration: A Workshop on Objectives, Methods, and Applicability to Policy and Practice (March 19-20, 2015, Washington, DC) [URL: http://blogs.worldbank.org/peoplemove/longitudinal-research-environmental-change-and-migration-workshop-objectives-methodsand, 24.11.2016].

Kumasssah, Agbotadua 2009: The migration saga of the Anlo-Ewe. Keta: Photo-City Press.

Laczko, Frank; Aghazarm, Christine (Eds.) 2009: Migration, Environment and Climate Change: assessing the evidence. Geneva: IOM.

MacGranahan, Gordon; Balk, Deborah; Anderson, Bridget 2007: The rising tide: assessing the risks of climate change and human settlements in low elevation coastal zones. In: Environment \& Urbanization 19,1: 17-37 [doi: 10.1177/0956247807076960].

Manning, Chris; Purnagunawan, Raden M. 2014: Regional labour markets in 2002-12: Limited convergence but integration nonetheless. In: Hill, Hal (Ed.): Regional Dynamics in a Decentralized Indonesia. Singapore: Institute of Southeast Asian Studies (ISEAS): 342-366.

Marfai, Muh A. et al. 2008: The impact of tidal flooding on a coastal community in Semarang, Indonesia. In: The Environmentalist 28,3: 237-248 [doi: 10.1007/s10669-0079134-4].

Marfai, Muh A. 2011: Impact of coastal inundation on ecology and agricultural land use. Case study in Central Java, Indonesia. In: Quaestiones Geographicae 30,3: 19-32 [doi: 10.2478/v10117-011-0024-y].

McLeman, Robert A.; Hunter, Lori M. 2010: Migration in the context of vulnerability and adaptation to climate change: insights from analogues. In: Wiley Interdisciplinary Reviews: Climate Change 1,3: 450-461 [doi: 10.1002/wcc.51].

MP3EI 2011: Master plan for the Acceleration and Expansion of Economic Development of Indonesia [URL: http://www.indonesia-investments.com/projects/government-development-plans/masterplan-for-acceleration-and-expansion-of-indonesias-economic-development-mp3ei/item306?, 24.11.2016]. 
Muhidin, Salahudin; Utomo, Ariane 2013: How many overseas Indonesians are there? Indonesia Diaspora Network - Research and Development (IDN - R\&D). Discussion Paper Series 1/2013. Jakarta: Indonesia Diaspora Network.

Muhidin, Salahudin 2014: Migration Patterns: people on the move. In: Hill, Hal (Ed.): Regional Dynamics in a Decentralized Indonesia. Singapore: Institute of Southeast Asian Studies (ISEAS): 317-342.

Mulyana, Wahyu et al. 2013: Urbanisation, Demographics and Adaptation to Climate Change in Semarang, Indonesia. Urbanization and Emerging Population Issues Working Paper 11. London: International Institute for Environment \& Development (IIED)/New York: United Nations Population Fund (UNFPA).

Myers, Norman 1983: Environmental refugees in a globally warmed world. In: Bioscience 43,11: 752-761 [doi: 10.2307/1312319].

Myers, Norman; Kent, Jennifer 1995: Environmental Exodus, an Emergent Crisis in the Global Arena.Washington: Climate Institute.

Neumann, Barbara et al. 2015: Future Coastal Population Growth and Exposure to SeaLevel Rise and Coastal Flooding - A Global Assessment. In: PLoS ONE 10,3: e0118571 [doi: 10.1371/journal.pone.0118571].

Paripurno, Eko T. 2006: Studies on cause and impact of flood disaster in central Java, Indonesia: a community-based disaster management perspective. In: Science and Culture 72,1-2 (Jan-Feb): 32-39.

Petersen, William 1958: A General Typology of Migration. In: American Sociological Review 23,3: 256-266.

Piguet, Etienne 2010: Linking climate change, environmental degradation, and migration: a methodological overview. In: Wiley Interdisciplinary Reviews: Climate Change 1,4, July/August 2010: 517-524 [doi: 10.1002/wcc.54].

Piguet, Etienne; PéCoud, Antoine; de Guchteneire, Paul 2011: Migration and climate change. UNESCO Pub. Cambridge: Cambridge University Press.

Ravenstein, Ernst G. 1885: The Laws of Migration. In: Journal of the Royal Statistical Society 52,2: 241-305 [doi: 10.2307/2979333].

Rogers, Sarah; Wang, Mark 2006: Environmental resettlement and social dis/re-articulation in Inner Mongolia, China. In: Population and Environment 28,1: 41-68 [doi: 10.1007/s11111-007-0033-x].

Soja, Edward 2015: Accentuate The Regional. In: International Journal of Urban and Regional Research 39,2: 372-381 [doi: 10.1111/1468-2427.12176].

Spaan, Ernst 1999: Labour Circulation and Socioeconomic Transformation: The Case of East Java, Indonesia. The Hague: Netherlands Interdisciplinary Demographic Institute.

Spaan, Ernst; Van Moppes, David 2006: African Exodus? Trends and patterns of International Migration in Sub-Saharan Africa. Working Paper Series Migration and Development - Working Paper 4. Nijmegen: Research Group Migration and Development, Radboud University Nijmegen.

Suhrke, Astri 1994: Environmental Degradation and Population Flows. In: Journal of International Affairs 47,2: 473-496.

Suryadinata, Leo; Arifin, Evi N.; Ananta, Aris 2003: Indonesia's Population. Ethnicity and Religion in a Changing Political Landscape. Singapore: Institute of Southeast Asian Studies (ISEAS). 
Tacoli, Cecilia 2011: Not only climate change: mobility, vulnerability and socio-economic transformations in environmentally fragile areas of Bolivia, Senegal and Tanzania. Human Settlements Working Paper Series. Rural-Urban Interactions and Livelihood Strategies - 28. London: Human Settlements Group, International Institute for Environment and Development (IIED).

Tankwanchi, Akhenaten B.S. 2012: Doctors beyond Borders - Data Trends and Medical Migration Dynamics from Sub-Saharan Africa to the United States. Dissertation. Nashville: Vanderbilt University.

Teye, Joseph K.; Setrana, Mary B.; Acheampong, Abigail, A. 2014: Migration of health professionals from Ghana: trends, drivers and emerging issues. In: Roscoe, Coleen (Ed.): Ghana: social, economic and political issues. New York: Nova Science Publishers: $253-274$.

Todaro, Michael P. 1976: Internal Migration in Developing Countries: A Review of Theory, Evidence, Methodology and Research Priorities. Geneva: International Labor Office.

Torvikey, Dzifa 2014: Adapting Once or Adapting Twice: Tongu Men and Women's Responses to the Damming of the Volta River. Presentation at Conference: Parallel worlds - Environmental Change, Regional Adaptation and the Role of Migration, 4.7.2014. Cologne: Universitat zu Koeln.

Tsikata, Dzodzi 2006: Living in the Shadow of the Large Dams. Long term responses of Downstream and Lakeside Communities of Ghana's Volta River Project. Accra: Woeli Publisher Services/Leiden: Brill.

U.S. Forest Service 2011: Biodiversity and Tropical Forests Environmental Threats and Opportunities Assessment. Washington: United States Agency for International Development (USAID).

UNDP United Nations Development Reports 2014: Human Development Report 2014. Sustaining Human Progress: Reducing Vulnerabilities and Building Resilience. New York: United Nations Development Programme.

United Nations, Department of Economic and Social Affairs, Population Division 2013a: Cross-national comparisons of internal migration: an update on global patterns and trends. Technical Paper 2013/1. New York: United Nations.

United Nations, Department of Economic and Social Affairs, Population Division 2013b: World Population Prospects: The 2012 Revision. Volume II. Demographic Profiles. (ST/ ESA/SER.A/345). New York: United Nations.

United Nations, Department of Economic and Social Affairs, Population Division 2014: World Urbanization Prospects: The 2014 Revision. Highlights. (ST/ESA/SER.A/352). New York: United Nations.

Van der Geest, Kees 2011: North-South migration in Ghana: What role for the environment? In: International Migration 49,1: 69-94 [doi: 10.1111/j.1468-2435.2010.00645.x].

Van der Velde, Martin; van Naerssen, Ton (Eds.) 2015: Mobility and Migration Choices. Thresholds to Crossing Borders. London/New York: Routledge.

Van Hear, Nicholas 1998: New Diasporas: the Mass Exodus, Dispersal and Regrouping of Migrant Communities. London: University College London Press.

Van Lottum, Jelle; Marks, Daan 2012: The Determinants of Internal Migration in a Developing Country: Quantitative Evidence for Indonesia, 1930-2000. In: Applied Economics 44,43: 4485-4494 [doi: 10.1080/00036846.2011.591735].

Yaro, Joseph A. et al. 2011: Migration and Population Dynamics: Changing Community Formation in Ghana. Technical Working Paper 2. Legon: Centre for Migration, University of Ghana. 
Yuniartanti, Rizki K.; Handayani, Wiwandari; Waskitaningsih, Novida 2016: Monitoring and evaluation effectiveness in flood early warning system project in Semarang City. In: International Journal of Society Systems Science 8,1: 49-77 [doi: 10.1504/ IJSSS.2016.076004].

Prof. Dr. Felicitas Hillmann ( $₫)$. Leibniz-Institute for Research on Society and Space, IRS Erkner/TU Berlin. Berlin, Germany. E-mail: Felicitas.hillmann@leibniz-irs.de URL: https://leibniz-irs.de/en/people-careers/staff/person/felicitas-hillmann-0227/

Ernst Spaan. Radboud Institute for Health Sciences, Radboud University. Nijmegen, The Netherlands. E-mail: ejaspaan@xmsnet.nl

URL: https://www.researchgate.net/profile/Ernst_Spaan 


\section{Comparative Population Studies}

wWW.comparativepopulationstudies.de

ISSN: 1869-8980 (Print) - 1869-8999 (Internet)

\section{Published by}

Prof. Dr. Norbert F. Schneider

Federal Institute for Population Research D-65180 Wiesbaden / Germany

\section{(cc) BY-SA}

2017

\section{Managing Editor}

Frank Swiaczny

\section{Assistant Managing Editor}

Katrin Schiefer

\section{Copy Editor}

(Selected Articles in German)

Dr. Evelyn Grünheid

\section{Layout}

Beatriz Feiler-Fuchs

E-mail: cpos@bib.bund.de

\section{Scientific Advisory Board}

Paul Gans (Mannheim)

Karsten Hank (Cologne)

Johannes Huinink (Bremen)

Michaela Kreyenfeld (Rostock)

Marc Luy (Vienna)

Notburga Ott (Bochum)

Peter Preisendörfer (Mainz)

Nikola Sander (Groningen)

Zsolt Spéder (Budapest)

\section{Board of Reviewers}

Martin Abraham (Erlangen)

Laura Bernardi (Lausanne)

Hansjörg Bucher (Bonn)

Claudia Diehl (Konstanz)

Andreas Diekmann (Zurich)

Gabriele Doblhammer-Reiter (Rostock)

Jürgen Dorbritz (Wiesbaden)

Anette Eva Fasang (Berlin)

E.-Jürgen Flöthmann (Bielefeld)

Alexia Fürnkranz-Prskawetz (Vienna)

Beat Fux (Salzburg)

Joshua Goldstein (Berkeley)

Sonja Haug (Regensburg)

Hill Kulu (Liverpool)

Aart C. Liefbroer (The Hague)

Kurt Lüscher (Konstanz)

Emma Lundholm (Umeå)

Nadja Milewski (Rostock)

Dimiter Philipov (Vienna)

Roland Rau (Rostock)

Tomáš Sobotka (Vienna)

Jeroen Spijker (Barcelona)

Olivier Thévenon (Paris)

Helga de Valk (Brussels)

Heike Trappe (Rostock)

Michael Wagner (Cologne) 